Wayne State University

DigitalCommons@WayneState

Anthropology Faculty Research Publications

Anthropology

10-1-2009

\title{
An Archaeological Perspective on the Andean Concept of Camaquen: Thinking Through Late Pre- Columbian Ofrendas and Huacas
}

Tamara L. Bray

Wayne State University, t.bray@wayne.edu

\section{Recommended Citation}

Tamara L. Bray (2009). An Archaeological Perspective on the Andean Concept of Camaquen: Thinking Through Late Pre-Columbian Ofrendas and Huacas. Cambridge Archaeological Journal, 19, pp 357-366. doi:10.1017/S0959774309000547.

Available at: http://digitalcommons.wayne.edu/anthrofrp/1 


\title{
An Archaeological Perspective on the Andean Concept of Camaquen: Thinking Through Late Pre-Columbian Ofrendas and Huacas
}

\author{
Tamara L. Bray
}

\begin{abstract}
Ethnohistoric sources suggest that the indigenous inhabitants of Andean South America saw both people and things as animated or enlivened by a common vital force (camaquen). In approaching the subject of camaquen archaeologically, I attempt to place objects and their materiality at the analytical centre, rather than the normally privileged ethnohistoric or ethnographic data, in order to see what new insights into the nature of Pre-Columbian ontologies might be gained from 'thinking through things'. In this, I follow recent theories premised on the idea that the traditional segregation of concepts and things may hinder understanding of alternative worlds. The study focuses specifically on the arrangements, relationality and referentiality between and among objects found in sacred and offering contexts dating to the Inca period.
\end{abstract}

The earliest Spanish reports of initial encounters with native Andean peoples render a sense of the profound strangeness experienced but not yet digested by the European invaders. The alien character of this new world can be detected in such comments as those of Miguel de Estete (1947) regarding the 'filthy wooden pole' worshipped as the great Andean oracle Pachacamac, or the reported wedding of a young girl to a sacred blue stone 'no bigger than the size of one's palm' (Avila 1918, 69-70, cited in Salomon 1991), or the confession that a ceramic pot dressed in female garb was venerated as the ancestor of a particular ayllu (Polia 1999, 505). Such observations suggest a radically different understanding of the nature and categories of being on the part of indigenous people in the Andes. Within the context of an emerging paradigm in anthropology that seeks to move beyond the dualist ontology of the subject/object-mind/matter split, this article is an initial attempt to explore the various hints offered in the ethnohistoric record regarding the existence of alternative, specifically Andean, ontologies. As an archaeologist, I am most interested in how the adoption of a different ontological footing might affect our interpretations of the archaeological record of the late Pre-Columbian Andes. After briefly discussing the significant features of this emergent theoretical stance advocating the idea of 'thinking through things', I highlight two key concepts brought forth in the ethnohistoric documentation with regard to Andean ontological assumptions, and then turn to a consideration of late Pre-Columbian sacred objects and offerings (ofrendas) in light of these. The reassessment of these archaeological phenomena from an ontological position that extends the notion of personhood to non-human entities is then reflected back upon our common understanding of these key indigenous concepts, enriching our reading of them through a recognition of their necessarily material and relational nature.

\section{The ontological turn in anthropology: thinking through things}

'What would an artifact-oriented anthropology look like if it were not about material culture' the authors of a recently published volume entitled Thinking Through Things ask? (Henare et al. 2007,1). Arguing against the $a$ priori distinction between matter and meaning, persons and things, representation and reality, they question the utility of this assumption from an anthropological point 
of view. They offer instead the radical suggestion that things might be treated sui generis as meanings $(2007,3)$ and take as their starting point the identity of meaning and thing, allowing that these may be one and the same, e.g. that things don't 'carry' meaning but are meaning. The ultimate aim of this refusal of the Western dichotomization of the mental and the material is to explore other ways of understanding and being in the world - the presumed remit of anthropology - and to work toward a reconfiguration of the analytical framework of the discipline.

The authors place their work on the continuum of what they describe as a quiet revolution in anthropology, characterized as 'the ontological turn' (Henare et al. 2007, 7-12). This turn involves a movement away from questions of knowledge and epistemology towards those concerned with ontology (see also Alberti \& Marshall, this volume). More specifically, they see it as a movement away from the habituation of anthropology to the exigencies of Cartesian dualism. From their perspective, the heuristic prescription of 'thinking through things' is what will enable us to go beyond the common sense assumption of 'one world, many worldviews', or the axiom that nature is one, while culture is many, which makes the job of anthropologists, then, the 'interpretation' of those other worldviews.

They derive the idea of multiple natural worlds (as opposed to multiple cultural views of nature) from the work of Viveiros de Castro $(1998 ; 2004)$ and the notion of 'perspectival multinaturalism' he developed on the basis of research into Amazonian cosmologies and ethno-metaphysics. As discussed by this author (2004, 464-4), a foundational ontological premise of many Amerindian peoples is that humanity, rather than animality, constitutes the original condition of all phenomena. From this, it follows that animals and other non-human entities, having once been human must still be; and while their bodily forms may conceal their interior subjectivity or core humanness, this aspect of their being is nonetheless understood to be formally identical to human consciousness.

The ontological presumption here is one of spiritual unity and corporeal diversity such that culture, or the subject, is the form of the universal, while nature, or the object, is the form of the particular (Viveiros de Castro 2004, 465). This differs profoundly from the modern Western belief in the unity of nature, leading Viveiros de Castro to the label 'multinaturalism' in order to contrast the Amerindian position with contemporary 'multiculturalist' ontologies (Viveiros de Castro 2004, 466). The perspectival aspect of Amerindian ontology as described by this author involves the understanding that every subject, whether human or non-human, has its own point of view, and that wherever there is a point of view, there is necessarily a 'subject position'. Rather than the subject being construed as the fixed entity from which the point of view emanates, however, in Amerindian theory, it is the point of view which is understood to activate or create the subject (Viveiros de Castro 2004, 467).

On the basis of such insights as those provided by Viveiros de Castro, Hallowell (1960) and others, Henare et al. (2007) argue that there may well be different worlds, not just different worldviews, and that it may be possible to access these by attending to the 'ontological anomalies' that we encounter as anthropologists in our engagement with others and their understandings of the world. Here I extend these ideas to the realm of archaeology.

\section{Ethnohistoric insights into native Andean ontologies: of persons and things}

A key Andean concept for purposes of present discussion is camay, a native Quechua term that has no clear equivalent in Spanish or English. Salomon \& Urioste $(1991,45)$ translate camay as 'to charge' or 'to charge being with', 'to make', 'to give form and force', or 'to animate' (see also Taylor 1974-76; 1987). Camay is fundamentally understood as a specific kind of essence, force, or power rather than as something abstract or generalized. Salomon $(1991,16)$ invokes the idea of 'species power' with respect to this term, as, for instance, in the case of the patron animals of shamans, who infuse the latter with their valued species traits, such as visual acuity, speed, or strength. Camay also carries the connotation of bringing something extant into being through the energizing of existing matter (as opposed to creating something from nothing). In the later sixteenth century for instance, ecclesiastical authorities who were intent upon precisely translating the Christian doctrine for native Quechua speakers rejected the use of the term camay in favour of the verb 'ruray' to refer to the creation of the universe, as the former term would have suggested 'a god that was the soul (or hidden principle) of the world rather than its creator' (Mannheim 1991, 66). ${ }^{1}$ Unlike the simple act of creation, which once done is over, camay intends something of continuity in sustaining the being, a condition that involves an on-going relationship between the camac (e.g. the 'camay-er') and its camasca (e.g. its tangible instantiation) (Salomon 1991, 16-17).

Many other cultures share a similar notion of a generative life force that infuses and animates all matter. In fact, such mana-like concepts are ubiqui- 
tous in early ethnographic literature, though, as one author recently commented, 'mana does not animate anthropological debate like it used to' (Holbraad 2007, 190). Relegated to the realm of the mythical, local concepts of life force, sacred power, etc. have been out of anthropological fashion for decades. In line with the ontological shift described above, the intent here is to recuperate the significance of camay, the Andean cousin of mana, for purposes of investigating its potential presence and materiality in the archaeological context. Because the notion of mana, or in this case - camay, cuts systematically across the Western divide between matter and meaning, attending to it anthropologically provides us with an analytical purchase from which to challenge the commonplace assumption that things must necessarily be considered ontologically distinct from concepts (Holbraad 2007, 191). The suggestion here is that we take what appears initially to us as an ontological anomaly, e.g. the notion that camay is both a thing and a concept, to create a new analytic frame in which an understanding that camay is both a stone and ritual efficacy, for instance, is not impossible.

Another key Andean concept for the present discussion is huaca. Garcilaso (1966, 76-7) attempted to convey the meaning of this term by enumerating the kinds of things called 'huaca' by native Andean peoples. His list included ' ... idols, rocks, great stones or trees', as well as things made, such as 'figures of men, birds, and animals' offered to the Sun, as well as places built, such as 'any temple, large or small, ... sepulchers set up in the fields... and corners of houses'. The term huaca, then, generally refers to 'a sacred thing', be it a place, idol, or image (Garcilaso 1966, 76-7). Cobo $(1990,44)$ suggested that the things Andean peoples worshipped, or huacas, could be divided into two categories: works of nature unaltered by human intervention, and 'idols that did not represent anything other than the material from which they were produced and the form given them by the craftsman who made them'. He goes on to note that 'all of these idols were worshipped for their own sake, and [that] these simple people never thought to search or use their imaginations in order to find what such idols represented' (Cobo 1990, 45; emphasis added). Cobo's seventeenth-century observations are stunning with regard to the utterly modernist buy-in vis-à-vis the separation of matter and meaning, and in light of the profound yet seemingly unconsidered insights he had into native Andean ontologies. Karsten (1949, 187) echoes a similar thought in his observation that '(t)here have even been attempts to explain them (e.g. huacas) in a "pre-animistic" way, not as seats of spiritual beings, but as places from which impersonal magical powers were emanating'.

Various indications in both ethnohistoric reports and the ethnographic literature suggest that 'huacas had vibrantly individual personalities' (Salomon 1991, 18; see also Salomon 1998). The stories recounted in the Huarochiri manuscript, for instance, lead Salomon $(1991,19)$ to conclude that the huacas are clearly living beings, 'persons in fact'. He goes on to note in his introduction to this manuscript that

the world imagined by the Checa does not seem to have been made of two kinds of stuff - (e.g.) matter and spirit - like that of Christians; (rather) huacas are made of energized matter, like everything else, and they act within nature, not over and outside it as Western supernaturals do (Salomon 1991, 19).

This insightful observation provides a segue to recent discussion on the intersection of materiality, agency and personhood.

\section{Objects, agency and personhood}

Much of the current theoretical work focusing on objects, agency and personhood takes as its starting point the influential writings of Alfred Gell (1992; 1996; 1998). Gell's basic thesis was that things, e.g. works of art, images, icons, etc., must be treated as 'person-like' - that is, as targets for and sources of social agency $(1998,96)$. In thinking through how things may be construed as persons, he developed a sophisticated conceptual framework outlining the way in which objects come to possess social agency - much like people. Within this framework, social agency is defined not in terms of biological attributes but rather relationally. In other words, it does not matter in ascribing social-agent status what a thing or a person 'is' in itself - what matters is where it stands in a network of social relations (Gell 1998, 123). Equally important here is the conditional and transactional nature of the relationship between persons and things (or 'patients and agents' to use Gell's terminology), each being necessarily constitutive of the other's agency at different moments in time (Gell 1998, 22).

Key to this discussion of agency and personhood is the shift of focus from the analysis of meaning to the analysis of effect. In other words, the concern is not so much with what objects mean - e.g. their semiotic significance - as with what they do. In this regard, objects are understood to act not with intentionality but rather through their effects, e.g. their efficacy. This approach is illustrated in Gell's $(1998,69-71)$ analysis of the ocean-going canoes involved in the Kula ring. For the Trobrianders, the beautiful carved prows 


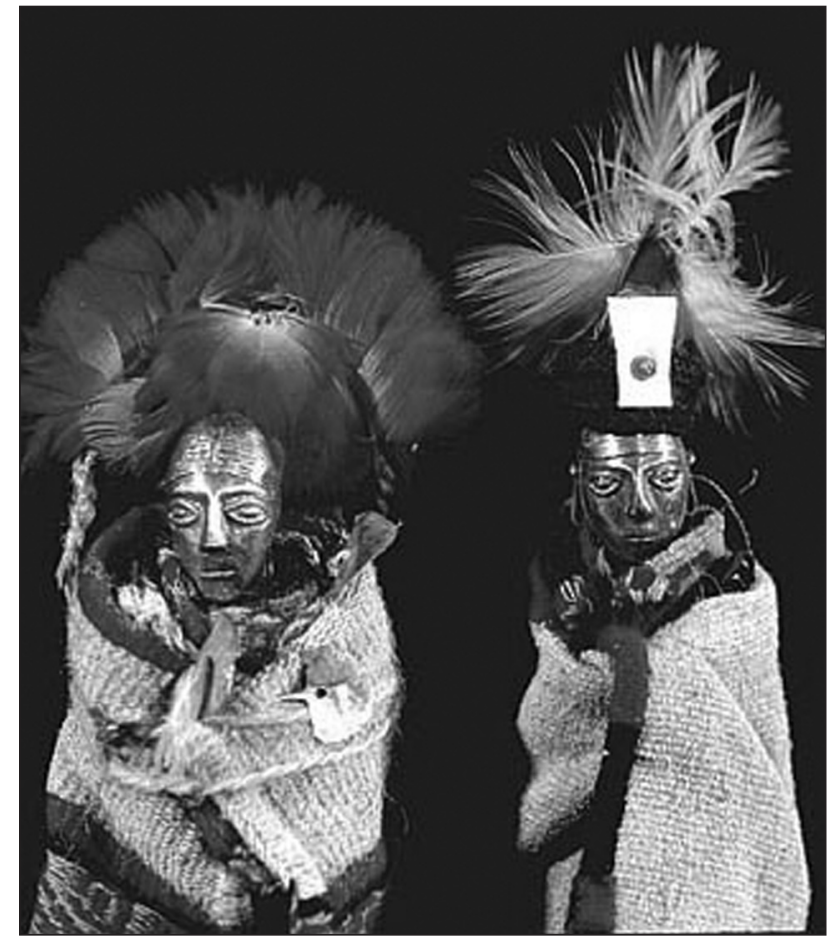

Figure 1. Inca miniature figurines from $\mathrm{Mt}$ Llullaillaco capacocha offering in Argentina. (Photograph courtesy of Johan Reinhard.)

of these vessels are made to enchant one's trading partners and to (favourably) affect the terms of the exchange. The canoes are thus seen as important agents in their own right within the social network of the Kula.

Archaeologically, the study of personhood potentially has much to contribute to our general understanding of what persons are and how personal identities may be construed beyond the dominant notion of Western individualism (e.g. Fowler 2004; Meskell 1999). Recent work in this area has foregrounded a relational view of personhood in which persons are seen as multiauthored, plural entities defined on the basis of what they do rather than on how they appear, and conformed of their many and various interactions within a kaleidoscopic field of social relations involving humans, animals, things and places (Brück 2001; Chapman 2000; Fowler 2004). From this perspective, social relations are seen to provide the grounds for and the context within which persons take (temporary) shape, with the nature of personhood consequently understood as contextual and shifting. Within the Andean context, the exploration of alternative forms of personhood and types of persons articulates closely with notions of power, agency, reciprocity and ethical obligation.
To illustrate this, I turn now to two categories of late Pre-Columbian artefact that most Andeanists would be willing to classify as ' $h u a c a$ ' based on common associations and context of finds. I divide these broadly into the categories of iconic and aniconic and consider each in light of the extended notions of personhood, animacy, agency and efficacy outlined above to see what, if any, new insights might be gained into native Andean ontologies by thinking through these things.

\section{Ofrendas and huacas}

\section{Iconic huacas}

The Inca are famous for their non-iconic approach to visual imagery, art and aesthetics. The principal exception to the non-figural dictate of the Inca aesthetic are the miniature human and camelid statues commonly associated with the important state ceremonial of capacocha (Fig. 1). One of the most momentous of imperial state occasions, the capacocha is understood from ethnohistoric accounts as having been linked to major events in the life history of Inca rulers - specifically coronation, severe illness and death (Betanzos 1996, 46, 132; Molina 1989, 120-27; Sarmiento 1965). The archaeological evidence, however, suggests that these miniature figurines may have also, and perhaps more importantly, been linked to the claiming or creation of sacred space by and for the imperial state. This observation is made on the basis of archaeologically documented finds of such objects at the sites of Túcume (Heyerdahl et al. 1995), Choquepukio (McEwan \& Gibaja n.d.), Isla de la Plata (Dorsey 1901), Tiwanaku (Yaeger pers. comm.), Lake Titicaca (Reinhard 1992a), Saqsaywaman (Valcarcel 1935, 180) and in the central plaza of Cuzco (Farrington \& Raffino 1996), among others. None of these sites comprise the high-altitude burial contexts with which we usually associate capacocha sacrifices or the miniature human and camelid figurines (see Ceruti 1999; Reinhard 1992b; Reinhard \& Ceruti 2000). Instead, a common denominator among these localities suggests a strong interest in physically claiming sacred sites and spaces that once belonged to powerful predecessors or rivals (but see Sillar, this volume, for a slightly different interpretation). Within this framework, the capacocha sacrifices made on the summits of important Andean peaks may be viewed as a special subset of such imperial acts (see McEwan \& van de Guchte 1992).

At the coastal site of Túcume, for instance, five Inca figurines were recovered from three dedicatory features situated around the entrance to the principal temple at the site. This temple had been in use several 
centuries prior to the Inca occupation (Heyerdahl et al. 1995). The ritually interred artefacts included one miniature silver female figurine recovered directly in front of the main entryway, one male and one female figurine of spondylus in a pit to the east of the doorway, and two female figurines, one of spondylus and one of silver, in a pit to the west. The large, canted stone guanca that constitutes the interior focal point of the principal temple at Túcume (Fig. 2) bears a striking resemblance to a similarly enclosed monolith uncovered by Gordon McEwan at the site of Choquepukio in the Cuzco basin, as do the reported finds of gold, silver and spondylus male and female figurines from this latter site (McEwan \& Gibaja n.d.). The special nature of the canted monoliths at these two sites, their probable revered status, and the like-

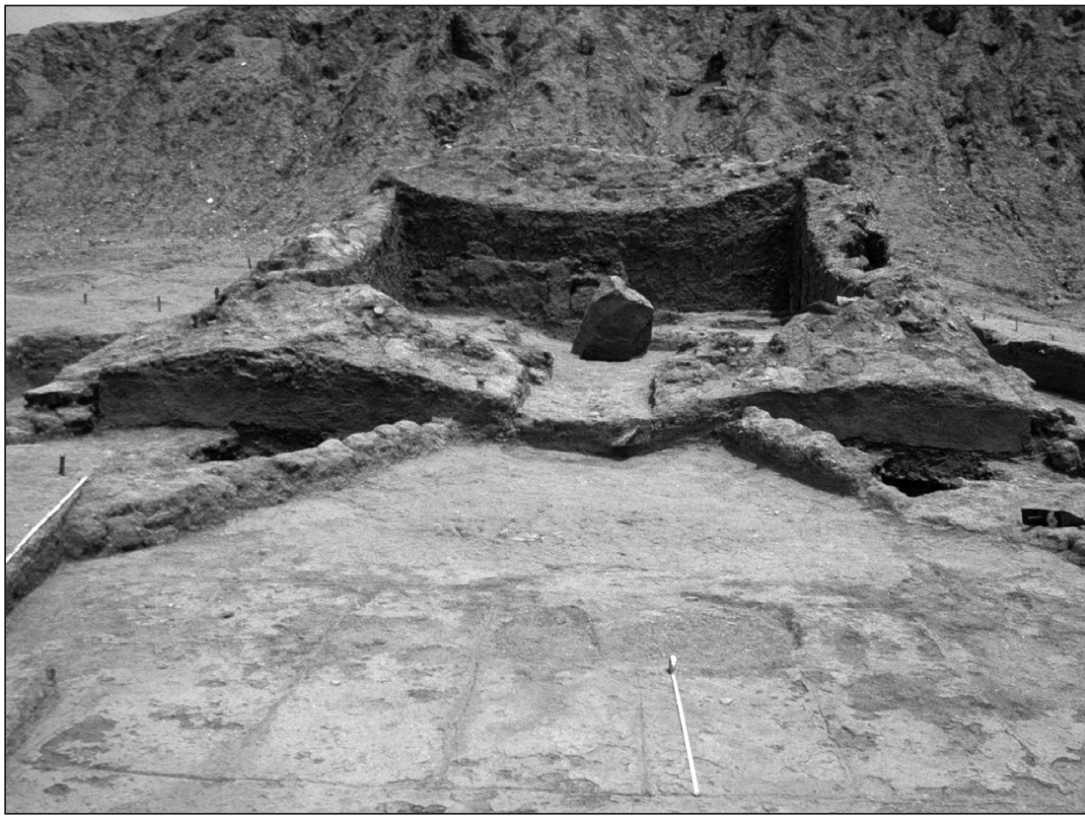

Figure 2. Sacred stone, or guanca, inside Temple of the Sacred Stone at Tucume. (Photograph courtesy of Dan Sandweiss, University of Maine.) lihood of their perceived potency is suggested by the special enclosures within which they were housed, the centrality of the stone and its housing vis-à-vis the rest of the site, and the fact that they were the recipients of special offerings - implying an expectation of reciprocity in the Andean context and the subject positionality of these objects in a network of social relations.

Similar observations can be made at various other important pre-Incaic sites that subsequently came to be dominated by the Inca. At Pachacamac, for instance, one of the principal centres of regional and religious power for at least a millennium prior to the rise of the Inca, a number of miniature human figurines were reportedly recovered (Baessler 1904). Among these was an unusually large male statue of silver that stands $24.3 \mathrm{~cm}$ tall, and another male specimen with bands of horizontal inlay (see Dransart $2000,78,80)$. Further north, off the coast of Ecuador, Dorsey (1901) excavated a double burial with five female figurines (three of gold, one of silver and one of bronze), tupu pins and Inca ceramics on the island of La Plata. Other archaeological material recovered from this island (Dorsey 1901), as well as ethnohistoric information (Cieza 1986), clearly indicate that La Plata island had long been a sacred huaca of the local inhabitants of the coastal mainland. In the Andean Altiplano to the south of Cuzco, Lake Titicaca was also the focus of regional worship and ritual activity long before the Inca incursion (Bauer \& Stanish 2001). In 1991,

two small stone boxes recovered from an underwater reef off an island in the middle of Lake Titicaca were found to contain five gold and silver male figurines and one miniature silver camelid figurine (Reinhard 1992a). ${ }^{2}$ In Cuzco, the ceremonial and political capital of the Inca empire, similar finds of miniature people and camelids suggest their role in the creation, as well as appropriation, of sacred space. Valcárcel (1935, 18), for instance, recovered a pair of silver female figurines during cleaning and excavation activities at the fortress complex of Saqsaywaman directly above Cuzco, while more recent archaeological work in the main plaza of Cuzco yielded four miniature camelid figurines - one of gold, two of silver and one of spondylus (Farrington \& Raffino 1996).

Two important aspects of these miniatures is that they were usually made to be anatomically correct and, though not all specimens have been equally well preserved, the human figures were likely all originally dressed in miniature versions of gender-appropriate clothing (Dransart 2000). That these objects were meant to be viewed as people seems unquestionable. Even the Spanish apparently recognized this, as indicated in one chronicler's comment that children intended as capacocha sacrifices were accompanied by 'persons of gold and silver'3 (Molina 1989, 122). That such objects were understood by the Inca as animate, person-like beings in their own right, e.g. as targets for and sources of social agency, also seems highly likely. 
This is suggested on the basis of the unique relational networks within which these objects were placed as well as the close attention to human anatomical and cultural detail with which they were crafted. When found in context, these miniatures are invariably positioned independently of but in clear relation to other person-objects (e.g. child sacrifices) and other object-persons (for example, guancas). As such, they seem to comprise part of a highly structured social network of subject-objects that existed not discretely but relationally. Following Cobo's observation that such idols were not seen to represent anything other than themselves (mentioned above), combined with Henare et al.'s (2007) advocacy of what they refer to as 'radical essentialism', it seems not unreasonable to infer that these objects were understood by the Inca to instantiate these relations rather than to 'stand for' them in some separate way, and that they were consequently viewed as efficacious social agents in their own right. In the rarified contexts in which they are typically found, these iconic miniature figures may have served in a capacity similar to that of huauques - the stone doubles or 'brothers' of Inca rulers (see van de Guchte 1996). In the case of the huauques, ethnohistoric sources report that these 'doppelgangers' appear to have operated independently of their human counterparts, commanding specific actions and behaviours in the absence of their corporeal doubles, as for instance in the leading of battles or the possession of personal property (van de Guchte 1996).

The unusual use of figural sculpture in situations that might be regarded as blatant cases of 'state appropriation' could be interpreted as a concern on the part of the Inca with eliminating any possibility of misconstrual with regard to meaning or intent. In these contexts, such an approach might be understood as a concession on the part of the Inca to a mimetic form of representation involving the human figure that afforded no possibility of misunderstanding by cultural 'outsiders'. It is worth noting here that the imperial predecessors of the Inca - the Huari and the Tiwanaku - made regular use of representational imagery in state art, indicating both cultural familiarity with such approaches and, perhaps, a conscious rejection of such on the part of the Inca, generally speaking (see Bray \& Cook n.d.).

Tacking back and forth between archaeological context, ethnohistoric data and ethnographic insights, I suggest that we may view Inca figurines - these miniature persons that were placed in highly charged ritual and political contexts - as power-full, or power objects imbued with the ability and the agency to serve as proxies for, or agents of, the State. Such a view is only possible, of course, if we open up to the possibilities of alternative ontologies or states of being beyond that of the dichotomized categories of subject/object, specifically with regard to the possibility of efficacy and agency. These power-full iconic objects existed side by side with perhaps less 'read-able' but equally powerful non-anthropomorphic huacas within the late Pre-Columbian realm.

\section{Aniconic huacas}

Turning now to the aniconic category of huaca, we know from the ethnohistoric data that Andean people venerated many kinds of 'natural' objects, including stones, rocks, wooden poles, trees and mountains - as is still the case in many parts of the highlands today (Fig. 3). As a class, these objects shared the characteristic of being non-anthropomorphic. But even though non-anthropomorphic and 'aniconic', such objects could nonetheless be considered 'representational', if we understand that the deity or force they were intended to 'represent' - the 'proto-type' to use Gell's term - was itself formless and shapeless. These huacas might thus be considered both wholly iconic and wholly aniconic at the same time. That they were understood as animate beings is clearly indicated by the kind of treatments such objects received - which included being fed, clothed and petitioned. The wooden pole that was the great oracle Pachacamac, the stone guancas at Chokepukio and Túcume, and the summits of the great snowcapped peaks (the apus), were all regular recipients of ritual offerings, and such gifts were undoubtedly made with entreaties and expectations of reciprocal obligations to be fulfilled. The notion of animacy involved here, however, is not one that should be construed in the biological sense but rather in the sense of possessing efficacy - as in having the ability to effect. As Gell notes,

to attribute to a stone the ability to 'hear' prayers is an example of animism, but it doesn't necessarily imply the belief that the stone is 'alive' in a biological sense. In other words, 'idols may be animate without.... being endowed with animal life or activity (Gell 1998, 122).

In the Andean realm, numerous native communities revered specific outcrops or stones as mythic ancestors and guardians. Such features were referred to by the Quechua term 'guanca'. Such objects were generally unmodified and aniconic. In Cuzco, for instance, the rock called Guanacaure was believed to be the lithified Inca sibling Ayar Cache who watched over the welfare of the city and to whom sacrifices were regularly made (Cieza 1986). Further north, in the province of 
Cajatambo, the local community worshipped 'a stone in the form of a man' who was their forbear and protector (MacCormack 1991, 408). In other cases, rocks were understood to be deities that had deliberately turned themselves to stone (see Salomon \& Urioste 1991). Though their external appearance changed, the identity of these objects apparently remained continuous with their original animate existence (cf. Viveiros de Castro 1992; also Salomon 1998). Unmodified stones could also represent the dead (Salomon \& Urioste 1991, 131), desired outcomes (Allen 1997), and personal protectors (Lumbreras 1979, 249). Interestingly, stones could also become people, as illustrated in the famous case of the field stones around Cuzco that rose up and turned into warriors to help Pachacuti defeat the enemy Chanca and defend the capital. Thus aniconic stone huacas and people apparently shared a similar kind of animating essence in the late PreColumbian world, as well as the ability to transform their outward appearances.

In his investigation of the huauque, or stone doubles of the Inca lords, van de Guchte (1996) develops the idea that stones were considered kinsmen within Inca society. However, though no huauque are known to have survived, it is unlikely that they were intended to have been actual physical representations of the Inca kings based on the ethnohistoric descriptions. In addition, as noted above, most Inca imagery was decidedly abstract and non-representational. Duviols (1977) has suggested that the stone brother-statues were likely much more than mere state portraits. Rather, they may well have been containers of the life force or energy - the camaquen - of the ruler, the essence that animated both the king and his stone double. I suggest here that stone may have been viewed as the camay of the imperial Inca elite - that the Inca may have viewed themselves as the tangible instantiation of the power of stone, sharing the animate 'stoney essence' of durability, permanence, and ubiquity with this important and elemental material of the Andean world. Again, such proposals are only possible if we allow for the possibility of alternative ontologies beyond the rigid dichotomization of subjects and objects (see also Groleau, this issue; Haber, this issue).

The sculptural modification of natural rock formations and outcrops is one of the most recognizable artefacts and signatures of the Inca empire. Such dramatic re-workings of the landscape may have been aimed at creating or distinguishing sacred space, or huacas, by externalizing or making visible the essence of the stone's sacred nature (Hemming \& Ranney 1982; Paternosto 1989). Examples of such stone huacas

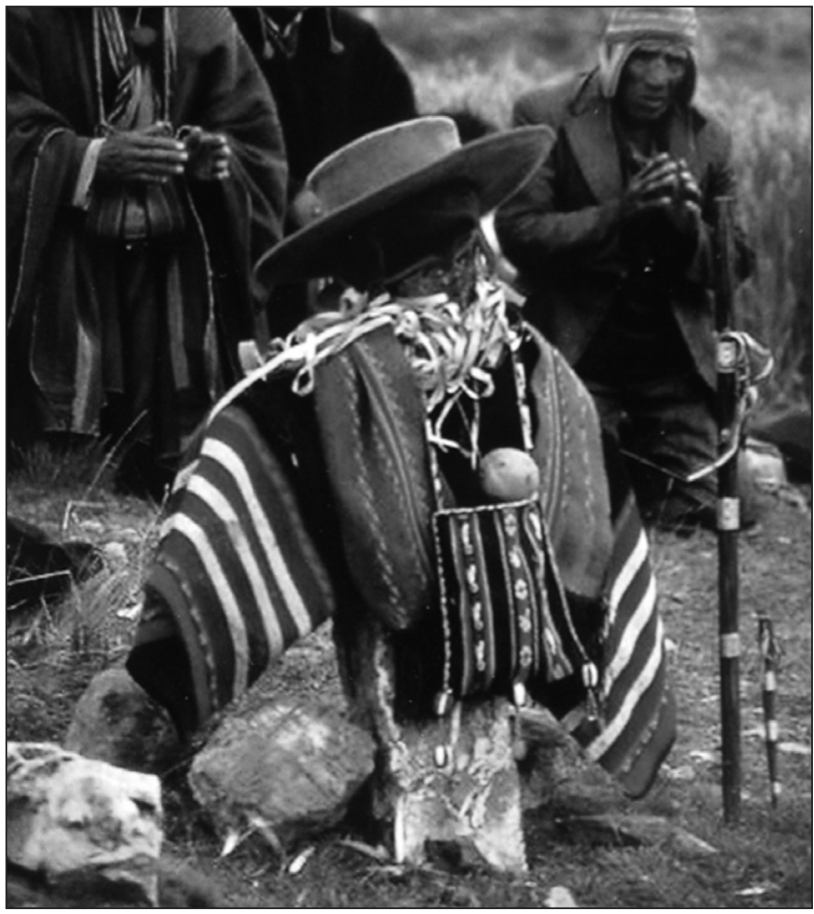

Figure 3. Dressed stone huaca in highlands of Bolivia being entreated by supplicants. (Photograph courtesy of Johan Reinhard.)

abound throughout the imperial realm, from Choquequilla and Quillarumi near Cuzco, to Copacabana in Bolivia, to Coyuntur in southern Ecuador (Fig. 4). In some cases, such as that of the 'puma rock' at Q'enqo and the 'sacred rock' at Machu Picchu, the stone huacas were minimally re-touched. In other cases, such as the numerous 'Inca thrones' and 'intiwatanas' found throughout the empire, the stone huacas were heavily sculpted by Inca masons (see Gasparini \& Margolies 1980; Paternosto 1989). This unique insistence on the special treatment of stone by the Inca again might reflect a special affinity to this particular substance.

While perhaps not every outcrop or boulder in the Andes was considered a huaca or a priori 'alive', it may be the case that every stone was viewed as having such potentiality. The main determinate of whether a particular stone object was understood as huaca seems to relate to whether or not that object had ever been previously involved relationally with other persons. Such social relations may be discernible archaeologically through special treatments or modifications accorded such entities, through the presence of offerings, through architectural demarcation, and/or through other contextual associations signalling special status. 


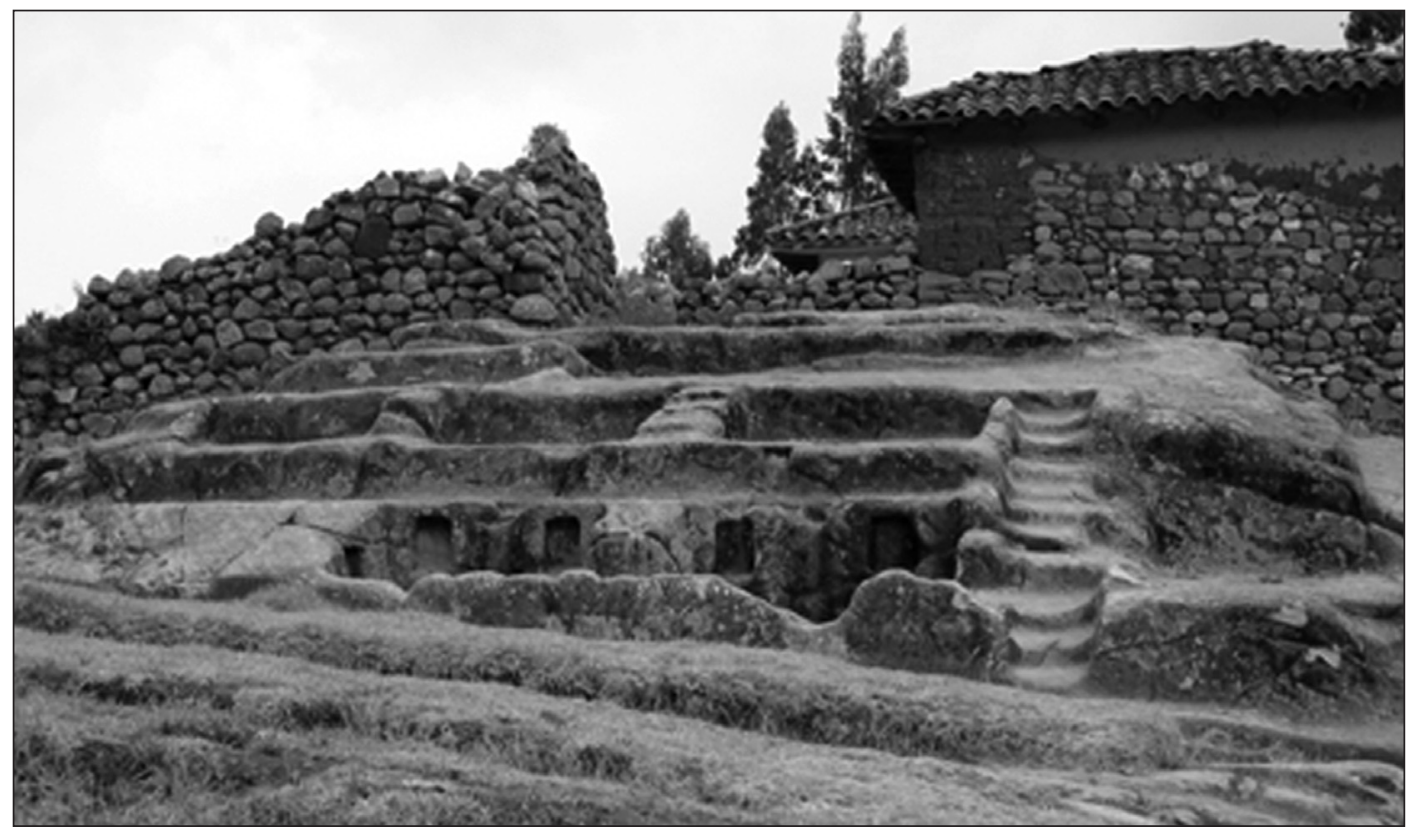

Figure 4. Inca carved outcrop, Coyuntur, southern Ecuador. (Photograph by Tamara Bray.)

\section{Closing thoughts}

Premised on the idea that the traditional Western divide between mind and matter may hinder our ability to conceptualize alternative understandings and categories of being, this article has explored the materiality of the Andean categories of huaca, or sacred things and camay. Two sub-categories of late Pre-Columbian huacas associated with the Inca state and identified on the basis of form, material type and context were considered, e.g. iconic and aniconic huacas. Thinking through these things in the ways outlined above offers new insights into Inca and Andean ontologies and understandings of being in the world. They suggest how the Inca may have construed and constructed their relationship to the material, cultural and spiritual worlds of which they were a part. They also offer possible examples of the ways in which the concept of camay was made manifest and material in the late Pre-Columbian world.

In thinking comparatively through the two subcategories of Andean huacas, there appear to be both important dimensions of contrast and similarity that open the door to future investigation. First, it seems that personhood and animacy were expressed for both iconic and aniconic forms through the metaphor of clothing (see also Bray 2008; Dransart 2000; Classen 1998). Dressing stones, dressing pots, dressing figurines and dressing buildings seems to have been a fundamentally Andean way of indicating the 'person- hood' of objects. The distinction required here in the consideration of dressed objects between animacy and inanimacy cuts across the categorical divide between living and non-living things, thus constituting an ontological anomaly from a dualist perspective. Such anomalies begin to suggest the inadequacy of our own categories of persons and things as concepts through which to apprehend the odd or special artefacts transmitted to us via the archaeological record and hold out the possibility of alternative understandings (see Zedeño, this issue).

With regard to iconic and aniconic huacas, there are also important dimensions of contrast that might usefully be explored. These may be considered along the lines of such issues as portability vs immobility, the idea of foreign or imported vs local/indigenous, and perhaps the significance of appearance vs essence. As demonstrated here, thinking through things helps extend our theoretical imaginations and allows us the possibility of potentially apprehending other and others' ontologies in a way that allows us to go beyond the dominant framework of Western dualism. In thinking through Andean huacas, we may begin to understand them as objective embodiments of the idea of power, their material form enabling concepts of power to have a presence and be efficacious in the world. At the same time, they suggest alternative ontologies of being, in which concepts and things are one and the same, or perhaps interchangeable. 


\section{Notes}

1. My thanks to Bill Sillar for drawing my attention to this reference.

2. A third box recovered at the same time was found to contain only three gold tupu pins - items usually associated with female garb; a gold female figurine was found on the lake bed several dozen metres away from the reef site which may have originally been associated with this third stone container (Reinhard 1992b).

3. '... y tomádolas, llevavan hasta la guaca, y allí ahogavan a los niños y los enterravan juntamente con las figuras de plata, de ovejas y de personas de oro y plata' (Molina 1989, 122).

\section{Tamara L. Bray \\ Wayne State University \\ College of Liberal Arts \& Sciences 4841 Cass Avenue 2155 Old Main Detroit, MI 48201 \\ USA \\ Email:ac9791@wayne.edu}

\section{References}

Allen, C., 1997. When pebbles move mountains, in Creating Context in Andean Cultures, ed. R. Howard-Malverde. Oxford: Oxford University Press, 73-84.

Avila, F. de, 1918. Informaciones acerca de la religion y gobierno de los Incas ... anotaciones y concordancias con las cronicas de Indias por Horacio H. Urteaga. Lima: Sanmarti y ca.

Baessler, A., 1904. Altperuanische Metallgerate. Berlin: Verlag von Georg Reimer.

Bauer, B. \& C. Stanish, 2001. Ritual and Pilgrimage in the Ancient Andes. Austin (TX): University of Texas Press.

Betanzos, J. de., 1996. Narrative of the Incas (1551), translated by R. Hamilton \& D. Buchanan. Austin (TX): University of Texas Press.

Bray, T.L., 2008. Exploring Inca state religion through the use of conceptual metaphors: a cross media analysis of Inca iconography, in Religion in the Material World, ed. L. Fogelin. Carbondale (IL): Southern Illinois University Press, 118-38.

Bray, T.L. \& A.G. Cook, n.d. Early Andean Empires and Corporate Art: a Comparison of Inca and Wari Ceramic Styles. Unpublished paper presented at the 64th Meeting of the Society for American Archaeology, Nashville, 1997.

Brück, J., 2001. Monuments, power, and personhood in the British Neolithic. Journal of the Royal Anthropological Institute 7, 649-67.

Ceruti, M.C., 1999. Cumbres Sagradas del Noroeste Argentino. Buenos Aires: Editorial Universitaria de Buenos Aires.

Chapman, J., 2000. Fragmentation in Archaeology: People, Places, and Broken Objects in the Prehistory of Southeastern Europe. London: Routledge.
Cieza de Leon, P. de., 1986. Crónica del Perú, segunda parte (1554), ed. F. Cantú. Lima: Fondo Editorial de la Pontificia Universidad Católica del Perú.

Classen, C., 1998. Inca Cosmology and the Human Body. Salt Lake City (UT): University of Utah Press.

Cobo, B., 1653. Historia del Nuevo Mundo (1653). (Biblioteca de Autores Españoles t.91-2.) Madrid: Editoriales Atlas.

Dorsey, G., 1901. Archaeological Investigations on the Island of La Plata, Ecuador. (Field Columbian Museum Publication 56; Anthropological Series, vol. II, no. 5.) Chicago (IL): Field Columbian Museum.

Dransart, P., 2000. Clothed metal and the iconography of human form among the Incas, in Precolumbian Gold: Technology, Style, and Iconography, ed. C. McEwan. London: Fitzroy Dearborn Publishers, 76-91.

Duviols, P., 1977. Un symbolisme andin du double: la lithomorphose de l'ancetre. Actes du XLIIe Congres International des Americanistes 4, 359-64.

Duviols, P., 1979. Un symbolisme de l'occupation de l'amenagement et de l'exploitation de l'espace. L'Homme 19(2), 7-31.

Estete, M. de, 1947. Relación del viaje que hizo el señor capitán Hernando Pizarro por mandado de su hermano desde el pueblo de Caxamarca a Parcama y de allá a Xauxa (1534), in Verdadera Relación de la Conquista del Perú y Provincia del Cuzco llamada Nueva Castilla, ed. F. de Xérex. Madrid: Biblioteca de Autores Españoles, 26, 338-43.

Farrington, I. \& R. Raffino, 1996. Moso suyukunapa tariqnin: nuevos hallazgos en el Tawantinsuyu. Tawantinsuyu 2, 73-7.

Fowler, C., 2004. The Archaeology of Personhood: an Anthropological Approach. London: Routledge.

Garcilaso de la Vega, el I., 1966. Royal Commentaries of the Incas and General History of Peru (1609). Austin (TX): University of Texas Press.

Gasparini, G. \& L. Margolies, 1980. Inca Architecture. Bloomington (IN): Indiana University Press.

Gell, A., 1998. Art and Agency: an Anthropological Theory. Oxford: Oxford University Press.

Gell, A., 1992. The technology of enchantment and the enchantment of technology, in Anthropology, Art and Aesthetics, eds. J. Coote \& A. Sheldon. Oxford: Clarendon Press, 40-67.

Gell, A., 1996. Vogel's net: traps as artwork and artwork as traps. Journal of Material Culture 1(1), 15-38.

van de Guchte, M., 1996. Sculpture and the concept of the double among Inca kings. RES: Journal of Anthropology and Aesthetics 29/30, 257-68.

Hallowell, A.I., 1960. Ojibwa ontology, behavior, and world view, in Culture in History: Essays in Honor of Paul Radin, ed. S. Diamond. New York (NY): Columbia University, 19-52.

Hemming, J. \& E. Ranney, 1982. Monuments of the Incas. Boston (MA): Little, Brown \& Co.

Henare, A., M. Holbraad \& S. Wastell (eds.), 2007. Thinking through Things. London: Routledge.

Hereydahl, T., D. Sandweiss \& A. Narvaez, 1995. Pyramids 
of Tucume. London: Thames and Hudson.

Holbraad, M., 2007. The power of powder: multiplicity and motion in the divinatory cosmology of Cuban Ifá (or mana, again), in Thinking through Things, eds. A. Henare, M. Holbraad \& S. Wastell. London: Routledge, 189-225.

Karsten, R., 1949. A Totalitarian State of the Past: the Civilization of the Inca Empire in Ancient Peru. Port Washington (NY): Kennikat Press.

Lumbreras, L., 1979. Religion and power in the Andes: idolatrous curacas of the central sierra. Ethnohistory 26(3), 243-63.

MacCormack, S., 1991. Religion in the Andes. Princeton (NJ): Princeton University Press.

Mannheim, B., 1991. The Language of the Inka since the European Invasion. Austin (TX): University of Texas Press.

McEwan, C. \& M. van de Guchte,1992. Ancestral time and sacred space in Inca state ritual, in Ancient Americas: Art from Ancient Landscapes, ed. R. Townsend. Chicago (IL): Art Institute of Chicago, 359-71.

McEwan, G. \& A. Gibaja, n.d. The Selz Foundation Excavations at Chokepukio, Cuzco, Peru: Report of the 2004 Excavations. Unpublished manuscript in possession of authors.

Meskell, L., 1999. Archaeologies of Social Life. Oxford: Blackwell.

Molina, C. de, 1989. Fábulas y Ritos de los Incas (1577), eds. H. Urbano \& P. Duviols. (Historia 16.) Madrid: Gráficas Nilo.

Paternosto, C., 1989. The Stone and the Thread: Andean Roots of Abstract Art. Austin (TX): University of Texas Press.

Polia, M., 1999. La Cosmovisión Religiosa Andina en los Documentos Inéditos del Archivo Romano de la Compañía de Jesús (1581-1752). Lima: Pontifica Universidad Católica del Perú, Fondo Editorial.

Reinhard, J., 1992a. Investigaciones arqueológicas subacuaticas en el lago Titikaka, in Arqueología Subacuatica en el Lago Titikaka: Informe Científico, eds. C. Ponce Sanguines et al. La Paz: Palabra Produccciones, 419-30.

Reinhard, J., 1992b. Sacred peaks of the Andes. National Geographic 181(3), 84-111.

Reinhard, J. \& M.C. Ceruti, 2000. Investigaciones Arqueológicas en el Volcán Llullaillaco. Salta: Ediciones Universidad
Católica de Salta.

Salomon, F., 1991. Introductory essay: the Huarochiri manuscript, in The Huarochiri Manuscript, eds. F. Salomon \& G. Urioste. Austin (TX): University of Texas Press, $1-38$.

Salomon, F., 1998. How the huacas were: the language of substance and transformation in the Huarochiri Quechua manuscript. RES: Journal of Anthropology and Aesthetics 33, 7-17.

Salomon, F. \& G. Urioste, 1991. The Huarochiri Manuscript. Austin (TX): University of Texas Press.

Sarmiento de Gamboa, P., 1965. Historia de los Incas (1572), ed. C. Saenz de Santa María. (Bibloteca de Autores Españoles 135.) Madrid: Bibloteca de Autores Españoles, 189-279.

Taylor, G., 1974-76. Camay, camac, et camasca dans le manuscrit quechua de Huarochiri. Journal de la Société des Americanistes 63, 231-43.

Taylor, G., 1987. Ritos y Tradiciones de Huarochiri del Siglo XVII. Lima: Instituto de Estudios Peruanos.

Valcárcel, L., 1935. Los trabajos arqueológicos en el Departamento de Cusco, Sajsawaman Redescubierto III-IV. Revista del Museo Nacional 4(1-24), 161-203.

Viveiros de Castro, E., 1998. Cosmological deixis and Amerindian perspectivism. The Journal of the Royal Anthropological Institute 4(3), 469-88.

Viveiros de Castro, E., 1992. From the Enemies Point of View: Humanity and Divinity in an Amazonian Society. Chicago (IL): Chicago University Press.

Viveiros de Castro, E., 2004. Exchanging perspectives: the transformation of objects into subjects in Amerindian ontologies. Common Knowledge 10(3), 463-84.

\section{Author biography}

Tamara Bray is an Associate Professor of Anthropology at Wayne State University, Detroit, Michigan. She specializes in the archaeology of Ecuador and the Inca empire. She is currently co-director of investigations at the site of Inca-Caranqui in northern Ecuador. Articles based on her research have in appeared in a variety of edited volumes and journals. 
Reproduced with permission of the copyright owner. Further reproduction prohibited without permission. 